\title{
- Current Updates of Special Issue on Oral Cancer
}

\section{Prof. Dr. Sachin Ingle}

IJCRR

Section: Healthcare

MIMSR Medical College, Latur, Maharashtra, India. Email: dr.sachiningle@gmail.co

\section{(c) (i) (3)}

Copyright@IJCRR

The special issue of Vol 12 issue 24 of IJCRR entitled "Impact, Awareness, Prevalence, Association, Detection, and Recent Demographic Surveys of Various Oral Cancer Forms" contains many articles, case reports of interest for the global biomedical readers, students and medical researchers. Article by Suvarna K. et al. on CA19 gene polymorphism in oral cancer is very informative for surgical oncologist and medical oncologists. Prevalence of oral cancer by Neha Sharma et al. shown the epidemiology of oral cancers. Research article by Aswani E. et al. explained well the prognosis of head neck squamous cell carcinoma by using HNRNPA2B1 EXPRESSION and its relation to prognosis. Review article by Sarojini K. on saliva based oral cancer diagnosis is useful to diagnose the conditions early. Awareness amongst the teenagers about risk factors of oral cancer is very valuable to reduce the incidence of oral cancer in India. The article by Sushma B. et al. highlighted all these factors and given insight to the youth of India. The role of radioimaging to evaluate osseous changes in oral cancers by Abhinaya LM is crucial to the radiologists. Overall all articles on the oral cancers are highly informative nicely written and turned out to be highly useful for postgraduates in surgery, Pathology, Oncosurgeons, Medical oncologists.

Once again, Thank you all contributors, Editors, Reviewers and the publisher - Radiance Research Academy Team, Nagpur (M.S.) India, Special thanks to Dr. Shilpa Ajay Pise, Executive Editor for her dedicated efforts, hard work and administration for publishing this special issue of the unique and common problem of oral cancers including all the facts epidemiology, pathology, Radiology, Cytology and surgical oncology. Best wishes for the Future prospectus and wish you all very happy New Year 2021!!

With Best wishes!!

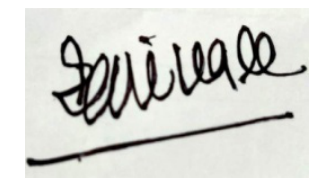

Professor Dr. Sachin B Ingle

The Editor In chief, IJCRR 